medRxiv preprint doi: https://doi.org/10.1101/2021.01.11.21249636; this version posted January 20, 2021. The copyright holder for this preprint (which was not certified by peer review) is the author/funder, who has granted medRxiv a license to display the preprint in It is made available under a CC-BY-NC-ND 4.0 International license.

\title{
Issues of Random Sampling with Rapid Antigen Tests for COVID-19 Diagnosis: A Special Reference to Kalmunai RDHS Division
}

\author{
AM Razmy \\ Faculty of Applied Sciences, South Eastern University of Sri Lanka \\ \& \\ SM Junaideen \\ Faculty of Engineering, South Eastern University of Sri Lanka
}

Email:amrazmy@seu.ac.lk

\begin{abstract}
Random sampling from the community and performing the rapid antigen test has become a debatable issue during this COVID-19 pandemic. This writing analyzes the concerns using the data from Kalmunai RDHS Division, Sri Lanka, related to COVID19 and shows the issues of random sampling in a community wherein the incident rate is small. Therefore, suitable sampling protocol is to be developed for performing rapid antigen test for COVID-19 diagnosis.
\end{abstract}

Keywords: COVID-19, random sampling, rapid antigen test, sensitivity, specificity

\section{Introduction}

Random sampling for diagnosing COVID-19 through rapid antigen test (RAT) is being carried out in different parts of the world. While the reliability of the test outcome is being widely debated, this writing attempts to elaborate the issues with random sampling in the community to detect COVID-19 infection through RAT. Mainly due to the specificity of testing kit, the reliability of the outcome is questioned. This issue creates complications in the community and health workers face numerous unwanted issues. The COVID-19 data available for Regional Directorate of Health Services (RDHS), Kalmunai, Sri
Lanka, has been used for elaborating the associated risks.

\section{Methodology}

\subsection{Data}

The COVID-19 data available for RDHS, Kalmunai, Sri Lanka, up to 10.00 am on 10.01.2021, is given in Table 1. This RDHS division has the population of 443,577 and it is located in the eastern part of the Sri Lanka. The total number of diagnosis test carried out is 22,334 in the 13 Medical Officer of Health $(\mathrm{MOH})$ sub divisions and these tests includes either PCR or RAT. The last two columns of this table give the number of incidents per 10,000 individuals and the number of tests done per 1,000 individuals for each $\mathrm{MOH}$ sub divisions. 
medRxiv preprint doi: https://doi.org/10.1101/2021.01.11.21249636; this version posted January 20, 2021. The copyright holder for this preprint (which was not certified by peer review) is the author/funder, who has granted medRxiv a license to display the preprint in It is made available under a CC-BY-NC-ND 4.0 International license .

Table 1. COVID-19 data for the Kalmunai RDHS Division as at 10.00 am on 10.01.2021

\begin{tabular}{|l|c|c|c|c|c|}
\hline \multicolumn{1}{|c|}{ MOH } & Population & $\begin{array}{c}\text { Positive } \\
\text { Cases }\end{array}$ & $\begin{array}{c}\text { TEST } \\
\text { (PCR \& } \\
\text { RAT) }\end{array}$ & $\begin{array}{c}\text { Incident } \\
\text { per } \\
\mathbf{1 0 , 0 0 0}\end{array}$ & $\begin{array}{c}\text { Test } \\
\text { per } \\
\mathbf{1 , 0 0 0}\end{array}$ \\
\hline AKARAIPATHU & 43392 & 310 & 4983 & 71.4 & 114.8 \\
\hline KALMUNAI(S) & 49488 & 229 & 3936 & 46.3 & 79.5 \\
\hline POTTUVIL & 38564 & 77 & 1272 & 20.0 & 33.0 \\
\hline SAINTHAMARUTHU & 28207 & 56 & 938 & 19.9 & 33.3 \\
\hline ADDALAICHCHNAI & 46495 & 88 & 2156 & 18.9 & 46.4 \\
\hline IRRAKAMAM & 15935 & 24 & 593 & 15.1 & 37.2 \\
\hline ALYADIVEMPU & 24880 & 36 & 2191 & 14.5 & 88.1 \\
\hline KARAITHIVU & 18656 & 21 & 1183 & 11.3 & 63.4 \\
\hline NAVITHNAVELY & 20748 & 16 & 549 & 7.7 & 26.5 \\
\hline NINTAVUR & 29205 & 18 & 1346 & 6.2 & 46.1 \\
\hline THIRUKOIL & 28004 & 15 & 840 & 5.4 & 30.0 \\
\hline KALMUNIA(N) & 33015 & 17 & 1322 & 5.1 & 40.0 \\
\hline SAMMANTHURAI & 66988 & 27 & 1025 & 4.0 & 15.3 \\
\hline \multicolumn{1}{|c|}{ TOTAL } & $\mathbf{4 4 3 5 7 7}$ & $\mathbf{9 3 4}$ & $\mathbf{2 2 3 3 4}$ & $\mathbf{2 1 . 1}$ & $\mathbf{5 0 . 3}$ \\
\hline
\end{tabular}

(Source: Kalmunai RDHS division)

\subsection{Sensitivity and Specificity of the RAT Kit}

There are many studies on the sensitivity [the rate of detecting infections correctly i.e., P (+/really positive)] and specificity [the rate of detecting non infections correctly i.e., $P$ (-/really negative)] of the RAT. When the RAT is used on people who were positive for COVID-19 in a standard PCR test, Abbott's antigen assay correctly spotted the virus in $95-100 \%$ of cases if the samples were collected within a week of the onset of symptoms. But that proportion dropped to $75 \%$ if samples were taken more than a week after people first showed symptoms.
The sensitivity of the other RAT used in the United States is between $84 \%$ and $98 \%$ if a person is tested in the week after showing symptoms [1]. European centre of disease prevention and control (ECDC) has performed a metaanalysis of the clinical performance of commercial four RATs and retrieved additional results of clinical evaluation studies of nine RATs from eight companies. This meta-analysis resulted the sensitivities and specificities against RT-PCR tests and ranged between $29 \%(95 \% \mathrm{Cl} 15.7$ 42.3) and $93.9 \%$ (95\% Cl 86.5-97.4) for test sensitivity and between $80.2 \%$ $(95 \% \mathrm{Cl} 71.1-86.7)$ and $100 \%(95 \% \mathrm{Cl}$ 
medRxiv preprint doi: https://doi.org/10.1101/2021.01.11.21249636; this version posted January 20, 2021. The copyright holder for this preprint (which was not certified by peer review) is the author/funder, who has granted medRxiv a license to display the preprint in It is made available under a CC-BY-NC-ND 4.0 International license .

98.8-100) for test specificity [2]. The differences in performance noted between the tests and between the studies can be partially explained by different populations and time of testing (proportion of persons that were tested early versus late in the course of the disease), and may also be affected by different RT-PCR assays used as goldstandard comparators, extraction methods or type of samples [3]. The WHO [4], Health Canada [5] and the US Centers for Disease Control and Prevention have recently issued guidelines for the use of RATs [6]. The WHO recommends RATs that meet the minimum performance requirements of $\geq 80 \%$ sensitivity and $\geq 97 \%$ specificity [4], while ECDC suggests aiming to use tests with a performance closer to RT$P C R$, i.e., $\geq 90 \%$ sensitivity and $\geq 97 \%$ specificity [3]. Since the WHO SouthEast Asia Regional Office and the WHO Sri Lanka supplied RAT kits to Sri Lanka [7], it is reasonable to assume the sensitivity and specificity of the RAT used in the Kalmunai RDHS division are $80 \%$ and $97 \%$ respectively.

\section{Analysis}

Figure 1 shows the COVID-19 incidents per 10,000 and the number of tests carried out per 1,000 for each $\mathrm{MOH}$ sub divisions in the Kalmunai RDHS division. In general, the incident rate has increased with the test rate in the population with some exceptions such as for the Alayadivempu, Karaithivu $\mathrm{MOH}$ sub divisions. This can be further investigated by the scatter diagram given in figure 2 .



Figure 1. Covid-19 incidents and test rate 


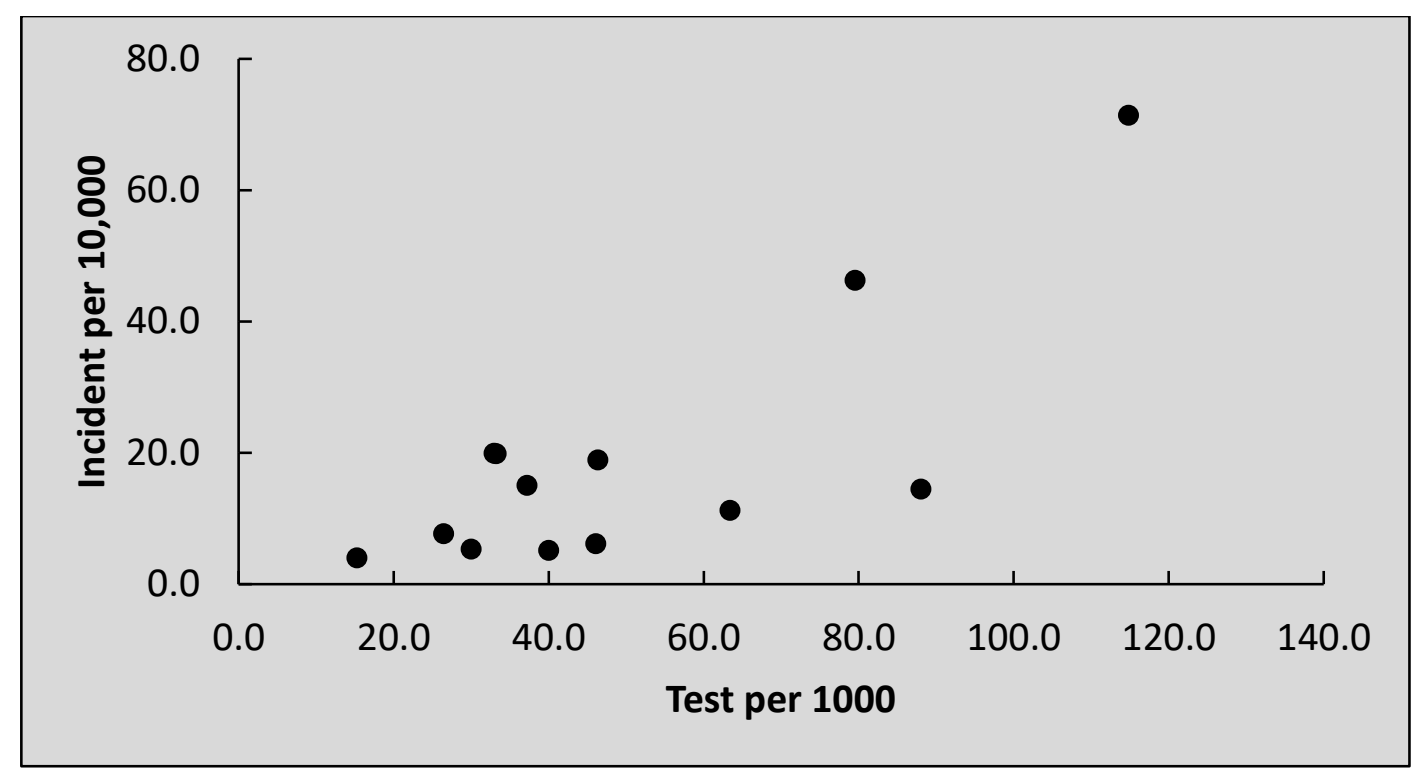

Figure 1. Scatter diagram to show the relationship between incidents and the test rate

If one assumes these tests are done at random, an enquiry strikes that the incident rate has increased with the increasing test rates. This paper is answering to this issue when using the RATs which has the sensitivity of $80 \%$ [Probability $(+/$ really positive $)=P(+/$ $C)=0.80]$ and the specificity of $97 \%$ [Probability (-/really negative) $=P(-/$ $\left.\left.C^{\prime}\right)=0.97\right]$, used in the Kalmunai RDHS division. The total number of positive cases identified in the Kalmunai RDHS division is 934 . Therefore, the incident rate can be considered as 0.0418 [The Probability (P) for the COVID-19 in the community $=P(C)=0.0418]$ assuming the tests were done at random. Considering these statistics, then the probability that an individual truly has COVID-19 given that a RAT has a positive result $[P(C /+)]$ is

$$
\begin{gathered}
P(C /+)=\frac{P(+/ C) P(C)}{P(+)} \\
=\frac{P(+/ C) P(C)}{P(+\cap C)+P\left(+\cap C^{\prime}\right)} \\
=\frac{P(+/ C) P(C)}{P(+/ C) P(C)+P\left(+/ C^{\prime}\right) P\left(C^{\prime}\right)} \\
=\frac{0.80 \times 0.0418}{(0.80 \times 0.0418)+[(1-0.97)(1-0.0418)]} \\
=0.538 .
\end{gathered}
$$

\section{Results and Discussion}

The analysis in section 3 says, in a community with 0.0418 incident rate, if the RATs are done randomly, the chance of that diagnosed person having COVID-19 in reality is only $53.8 \%$ and $46.2 \%$ of the positive diagnosis are done wrongly. It has to be noted that the incident rate was estimated as 0.0418 assuming all the tests 
medRxiv preprint doi: https://doi.org/10.1101/2021.01.11.21249636; this version posted January 20, 2021. The copyright holder for this preprint (which was not certified by peer review) is the author/funder, who has granted medRxiv a license to display the preprint in It is made available under a CC-BY-NC-ND 4.0 International license .

were done randomly but in reality, it is not. Purposive samples were also there in the total of 22,334 samples. Therefore, this estimated incident rate should be less than the value of 0.0418 , which will increase the false positives further. This result can be enlightened by the figure 3 based on the statistics available. In a community with 10,000 individuals, there will be a large number of individuals $(\approx 9582)$ without COVID-19 against the $\approx 418$ COVID-19 patients. If all 10,000 individuals are tested with RAT, with the said sensitivity, $\approx 335$ of the 418 COVID-19 patients will be diagnosed for COVID-19. With the said specificity, $\approx 228$ individuals of the 9,582 non COVID-19 individuals will diagnosed for COVID-19 wrongly. This proves that when the incident rate is small in the community and the test kits are used at randomly, large number of false positives cases can be observed.

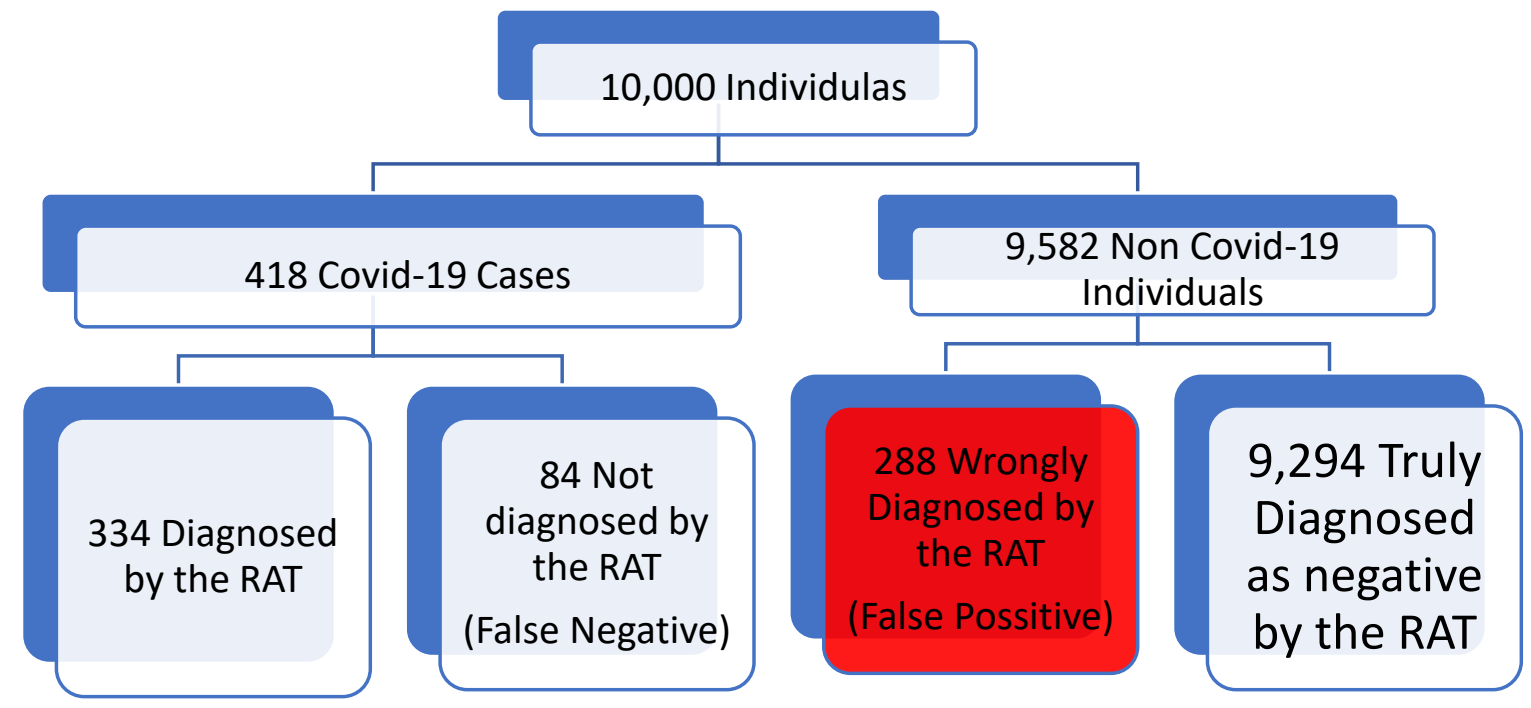

Figure 3. Explanation for the results

\section{Conclusion}

There are large number of non-COVID-19 cases in the population (95.8\%). Since the test has $97 \%$ specificity, $3 \%$ of the nonCOVID-19 cases are falsely identified as case. This issue drastically reduces the reliability of the test to $53.8 \%$ when one gets positive diagnosis. This reliability will go further down since the estimated incident rate was based on the assumption of random sampling which is not true in every case. Therefore, a suitable protocol is required for the sampling the mechanism when performing RATs in the community. However, the figure 1 can't be an absolute example for question arisen that more tests-more positive since all sample were not obtained at random and PCR tests were also used for the diagnosis. 
medRxiv preprint doi: https://doi.org/10.1101/2021.01.11.21249636; this version posted January 20, 2021. The copyright holder for this preprint (which was not certified by peer review) is the author/funder, who has granted medRxiv a license to display the preprint in It is made available under a CC-BY-NC-ND 4.0 International license .

\section{Reference}

1. Guglielmi, G. (2020, September 16). Fast coronavirus tests: what they can and can't do. Nature, 585 , 496-498.

https://doi.org/10.1038/d41586-

\section{0-02661-2}

2. Van Walle, I., Leitmeyer, K., \& Broberg, E. K. (2020). Metaanalysis of the clinical performance of commercial SARS-CoV-2 nucleic acid, antigen and antibody tests up to 22 August 2020. medRxiv, 2020.09.16 (20195917).

https://doi.org/10.1101/2020.09.1

\section{$\underline{6.20195917}$}

3. European Centre for Disease Prevention and Control. (2020). Technical Report: Options for the use of rapid antigen tests for COVID-19 in the EU/EEA and the UK. ECDC: Stockholm. https://www.ecdc.europa.eu/sites/ default/files/documents/Optionsuse-of-rapid-antigen-tests-forCOVID-19.pdf

4. World Health Organization. (2020). Coronavirus disease (COVID-19) Pandemic Emergency Use Listing Procedure (EUL) open for in vitro diagnostics. WHO: Geneva. https://www.who.int/diagnostics I aboratory/EUL/en 12.

5. Government of Canada. (2020). Interim guidance on the use of rapid antigen detection tests for the identification of SARS-CoV-2 infection. Department of Public Health Services, Canada. https://www.canada.ca/en/publichealth/services/diseases/2019novel-coronavirusinfection/guidancedocuments/use-rapid-antigendetection-tests.html

6. Centers for Disease Control and Prevention. (2020). Interim Guidance for Rapid Antigen Testing for SARSCoV-2. National Center for Immunization and Respiratory Diseases, USA. https://www.cdc.gov/coronavirus/ 2019-ncov/lab/resources/antigentests-guidelines.html

7. World Health Organization. (2020). WHO supplies rapid antigen detection tests for COVID19 response. WHO: Geneva. https://www.who.int/srilanka/news /detail/09-11-2020-who-suppliesrapid-antigen-detection-tests-forcovid-19-response 